\title{
Growth and the Investment Climate: Progress and Challenges for Asian Economies
}

\author{
Lauren M. Phillips
}

\begin{abstract}
1 Introduction
Many Asian countries have been able to maintain rates of growth well above 6 per cent in real terms over the course of two decades. The Asian Development Bank (ADB) reports that with the exception of Pacific developing countries, nearly all countries in Asia grew at more than 5 per cent in 2004 (ADB 2005). Therefore one of the primary challenges for Asian governments and international partners in the coming decade is to ensure that growth continues in states where performance has been strong, and to increase growth in lagging regions and states where growth has been weaker.

The trend in high growth described above has been possible in part due to high investment levels by both domestic and international firms (see Table 1 for
\end{abstract}

selected Asian economies gross investment rates). A key element to ensuring future levels of growth and improvements in growth rates in areas where it has been absent is to continue improving the conditions under which firms are able to invest and reap reward from their investments, or strengthening the investment climate.

The investment climate is the broad set of political, economic, legal and physical factors which make a given country an attractive destination for foreign investment, and a place in which domestic entrepreneurs of all sizes and across industries are willing to invest. Thus, while the investment climate has many components, it is possible to subdivide the components into two primary sets of variables: governance and infrastructure. Governance refers to

Table 1 Gross fixed investment in selected Asian countries (\% of GDP), 2001-5

\begin{tabular}{lllllll}
\hline & $\mathbf{2 0 0 1}$ & $\mathbf{2 0 0 2}$ & $\mathbf{2 0 0 3}$ & $\mathbf{2 0 0 4}$ & $\mathbf{2 0 0 5}$ & Average \\
\hline China & 38.4 & 38.8 & 42.1 & 43.8 & 43.6 & 41.3 \\
India & 21.9 & 22.2 & 22.7 & 23.7 & $\mathbf{2 4 . 8}$ & 23.1 \\
Indonesia & 19.3 & 19.0 & 18.9 & 21.0 & 21.4 & 19.9 \\
Malaysia & 24.9 & 23.1 & 22.1 & 20.5 & 20.5 & 22.2 \\
Pakistan & 15.9 & 15.5 & 15.3 & 15.6 & 15.3 & 15.5 \\
Philippines & 18.0 & 17.6 & 16.7 & 16.5 & 16.1 & 17.0 \\
Sri Lanka & 22.3 & 21.1 & 21.9 & 24.9 & 27.1 & 23.4 \\
Thailand & 23.0 & 22.8 & 24.0 & 25.9 & 29.5 & 25.0 \\
Vietnam & 29.1 & 31.1 & 33.3 & 33.3 & 37.6 & 32.9 \\
\hline
\end{tabular}

Economist Intelligence Unit. 
characteristics such as corruption, transparent judicial systems, favourable competition policy etc. Infrastructure includes both hard infrastructure (irrigation systems, ports, roads, bridges, airports) and soft infrastructure (telephony, other technologies etc.).

In a number of countries, the Asian growth experience challenges commonly accepted paradigms about the relationship between investment conditions and growth. For example, while the extensive literature on the investment climate places a strong emphasis on governance, many of the countries in Asia have experienced both high growth rates and high levels of investment in the past two decades despite levels of corruption and regulations which are inconsistent with 'best practice' as defined in the literature. Thus, parts of the Asian region demonstrate that achieving growth is certainly possible without implementing a comprehensive set of investment climate reforms. However, this observation fails to take into account that substantial rates of growth and productivity may have been lost by having such arrangements in place. Research detailed in this article shows that incremental improvements in the investment climate have a strong impact on growth rates.

It is also worth noting that when looking at the micro-data on the investment climate in the Asian region as a whole, there are few trends which appear to be consistent across the region. The investment climate varies dramatically among Asian countries as well as between cities, regions and industries. One of the few general features of the data is that the investment climate in South Asia has more infrastructure and regulatory barriers than does the investment climate in South-east and East Asia (Rahman 2005). There is also indication in the microdata that two 'priority' components are the time it takes to get business done in many parts of Asia and severe infrastructure-based constraints in some countries, regions and cities.

This article seeks to evaluate the current progress on creating a favourable climate for investment in Asia. The first section is a conceptualisation: it offers a definition of the investment climate and discusses individual components, looks at the empirical links between growth and the investment climate and raises the question of whether investment climate policy should be centralised or decentralised. The second section looks at how challenges to doing business vary across types of firms (from small family farms and other small enterprises to large domestic and multinational firms). The third section analyses the micro-data on the investment climate in Asia. The final section takes a pragmatic approach to the investment climate by analysing the constraints and political economy costs of implementing investment climate as well as outlining potential partnerships which can be built both within the Asian region and among Asian governments and international agencies to facilitate evaluation and reform of the investment climate.

\section{Conceptualising the investment climate 2.1 Defining the investment climate}

The first necessary step in a discussion of the impact of investment climate improvements on growth and poverty reduction is to provide a definition of the concept. Definitions are generally broad, though relatively consistent among authors. The World Bank's World Development Report 2005: A Better Investment Climate for Everyone states: 'The investment climate reflects the many location specific factors that shape the opportunities and incentives for firms to invest productively, create jobs, and expand' (World Bank 2005: 2). A more specific definition arises from Dollar et al. (2003: 2), where economic fundamentals and hard infrastructure are left out: 'The institutional, policy and regulatory environment in which firms operate - factors that influence the link from sowing to reaping'.

The behaviour of the government is central to both of these definitions as policy choices help to define the contours of the investment climate. As such, the concept of the investment climate is strongly linked to studies which emphasise the importance of governance, high-quality institutions and social infrastructure in generating growth. Generally, the preconditions to growth summarised by the concept of a healthy investment climate include: economic and political stability, rule of law, adequate infrastructure, tax and regulations conducive to doing business, labour policies and access to finance, about which more is said in the bullet points below which are subdivided into governance and infrastructure categories. This list overlooks the importance of other factors, such as skill levels and education of the workforce and existing conditions, such as geography and access to international markets in competitive products, but is a broad concept. 


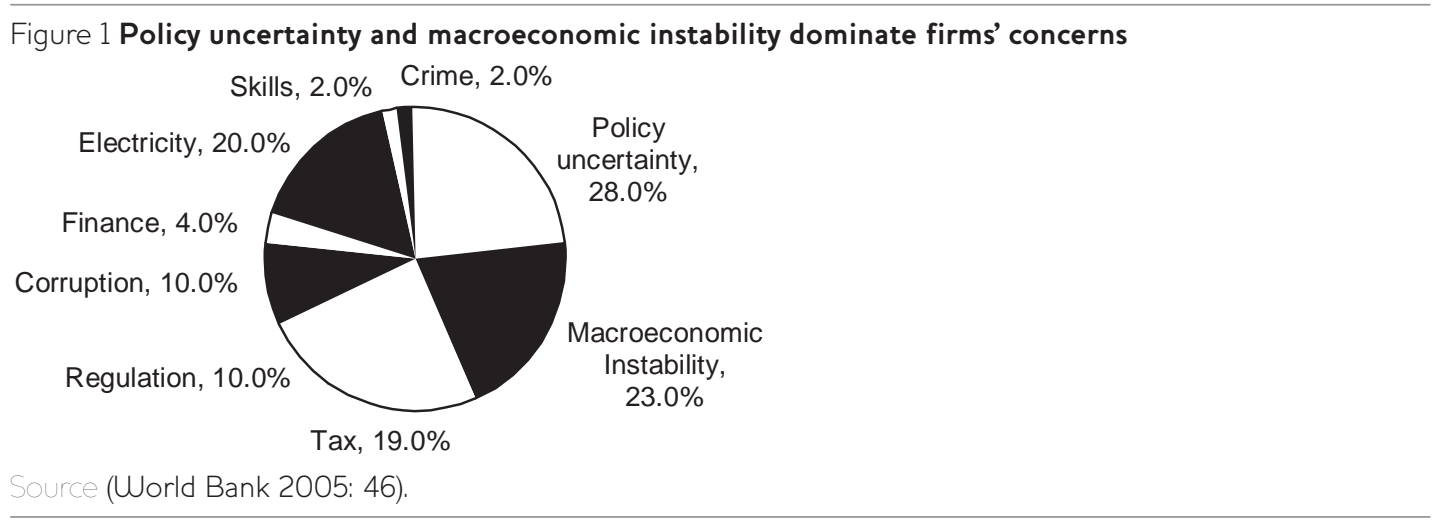

\subsection{Governance components}

- Macroeconomic and political stability is the broadest component of the investment climate (and the one that is arguably the least directly driven by concerns for promoting and maintaining investment); it is the economic and political context in which firms are investing. The Investment Climate Surveys (ICS) suggest that policy uncertainty and macroeconomic instability together account for more than half of firms' concerns about the investment climate (Figure 1).

- The strength of the legal system reinforces perceptions of political stability and reaffirms property rights by giving investors recourse for contestation.

- Corruption can also undermine growth and incentives to participate and invest in the formal economy. Again, however, there are counter examples in the Asian region in which systems of political economy organisation which have been classified by external observers as 'corrupt' or 'crony-istic' have actually had a positive impact on growth rates and investment incentives.

- Regulations cover things as diverse as the facility with which companies can start and close a business, to tariff and customs regulations. $A$ healthy investment climate is not driven by reduction in regulation per se, but rather appropriate regulation that can be implemented without decreasing investment incentives or unduly increasing costs (Stone 2005). Tax forms one significant part of the set of regulations facing businesses, as seen in Figure 1. Reform of tax structures and administration helps to minimise compliance costs and therefore encourage investment - and thus the purpose of tax reform is not simply to reduce the tax burden but rather to design appropriate taxation for different types of business and industry. Competition also conditions the quality of the investment climate: inappropriate/excessive regulation, and a lack of competition arising from the action of either business or government, can reduce the incentive to invest. Labour policies are partially conditioned by regulations - such as the time it takes to hire and fire an employee - but also deal with more social considerations, such as the skill and diversity of the workforce (including gender).

\subsection{Infrastructure components}

- Infrastructure is also a basic and critical element of the investment climate and can be usefully divided into 'hard' infrastructure such as the quality of roads, irrigation, ports and airports and 'soft' infrastructure such as the quality of provision of electricity, water and telephony. Both categories are critical to production and trade within and beyond borders, and infrastructure often appears among the top three barriers to investment in assessments (particularly in the South Asian context). ${ }^{2}$ Technology is an essential part of increasing the functionality of soft infrastructure for example, widespread use of mobile telephony, a cheaper alternative to lying extensive land line cables, have provided those in rural areas with needed access to information.

- Financial systems are also critical to investment. A functioning financial sector encourages investment by mobilising savings as well as permitting investors to manage risk. The financial sector also plays a crucial role in poverty reduction: 'Financial sector development can also reduce poverty. First, it has an indirect effect, through the positive impact on growth. It can also have a more direct impact to the extent that it results in increased access to financial services 
for the poor' (Ellis 2005: 1). Access to a savings account, to credit, to insurance, and to remittances, also reduces vulnerability by allowing households to better manage fluctuations in income, and enables poor people to invest in essential services like health and education. ${ }^{3}$

\subsection{The empirical relationship between the investment climate and growth}

What empirical evidence exists to demonstrate a clear and positive link between a conducive climate for investment and economic growth (and perhaps, poverty reduction)? Most studies (including those by the World Bank) have sought to demonstrate that the quality of the investment climate contributes to growth via its role in determining total factor productivity (Dollar et al. 2003). Total factor productivity (TFP) is by definition the residual growth not explained by changes to capital or labour, and is a notoriously difficult concept to measure accurately. Recent work has attempted to proxy for TFP with the quality of a country's institutions, such as security of property rights or rule of law. As such metrics are related to the investment climate, the investment climate is related to growth. An additional link between the investment climate and growth comes in through discussing the impact of foreign direct investment (FDI) on growth, and the link between the investment climate and increased FDI. Finally, there is a link between functioning and accessible agricultural markets, growth and poverty reduction: improved agricultural productivity also stabilises and reduces the price of food, and most critically, has particularly strong linkages to growth in non-farm sectors.

To provide some examples of the links between growth and the investment climate in Asia, a recent study by the McKinsey Global Institute ${ }^{4}$ estimated that gross domestic product (GDP) growth in India could be increased by more than 4.0 per cent a year by implementing reforms to the investment climate. In particular, the study suggested that the current growth trajectory of 5.5 per cent could be increased in the following increments: reform of sectorspecific regulations (1.6 per cent), resolving land market issues (1.0 per cent), reducing unequal enforcement of laws and the 'informality trap' (1.0 per cent), reducing government ownership (0.7 per cent), and other (including reforms to the labour market, education sector and infrastructure) 0.3 per cent, for a total of 10.1 per cent potential growth (Palmade 2005: 3).

\subsection{Centralised or decentralised investment policies?}

A question directly related to the above is whether governments should conceive of the investment climate in a unified way (a centralised investment climate policy) or as a series of individual policies which together create an investment climate (a decentralised policy). The World Bank argues that the greatest utility from the investment climate concept may come from thinking about such concepts as a 'package,' where all elements are considered as part of the overall investment climate as analysed by firms deciding on investment priorities (World Bank 2005: 56). This is in part because a disaggregated strategy runs the risk of creating destructive national competition between cities or regions that are attempting to attract investment via tax incentives and other fiscal means (see for example the extensive literature on the 'guerra fiscal' or fiscal wars between Brazilian states in the 1990s including Serra and Afonso 1999 and Castanhar 2003). Additionally, building up an investment policy through individual initiatives may increase the potential for entrenching special interests and therefore increase resistance towards future reform.

\section{Asian examples of improving the investment climate}

The investment climate as described above matters for many types of investors: large domestic firms and multinationals as well as micro, small and medium enterprises (including rural workers such as farmers) all rely on a healthy investment climate to make business decisions and in turn generate growth. However, the challenges facing firms often vary. This section not only seeks to identify challenges across types of firms, it also provides case studies of successful efforts in Asia to improve the investment climate. Case studies are useful in identifying strategies which have been successful in one context, though 'There are no universal "best practice" routes for working with private business to deliver ... services' (DFID 2005a: 12), and thus each case should be evaluated in its own right.

\subsection{Asian investment climate in the agricultural and rural context \\ Gains to agricultural productivity reduce poverty by lowering food prices, raising farmers' incomes (despite market adjustment from increasing output) and creating employment opportunities (DFID 2005b). There is little evidence that other sectors can}




\section{Box 1 Enhancing access to finance in rural India}

The Kisan Credit Card, offered by commercial, rural and cooperative banks, is a technological innovation in providing credit to the agricultural sector in India, including small farmers. Since its introduction in 1998-9, some 31.6 million cards had been issued by April 2003. Though not truly credit cards, the cards have advantages for borrowers and lenders. They make it easier to get credit and renew loans, once the initial screening has been done. They reduce the number of visits to branches, and they increase the operation of accounts at designated supply branches.

The increasing sophistication of financial markets is helping farmers smooth their incomes in the face of fluctuating prices and harvests. Fledgling futures markets are allowing them to fix the prices they will receive in advance. Innovations in insurance are allowing them to protect themselves from losses caused by poor weather. The payouts are based on an index measuring local weather, which allows an objective determination of the payout and maintains farmers' incentives to maximise their output despite poor weather.

'Expanding access to finance in rural areas - new approaches in India', World Development Report 2005, World Bank (2005: 120).

replace agriculture in its primary growth role in areas and regions that remain at a low level of development. Evidence from Asia shows that livelihoods were highly diversified before the Green Revolution, but it took dramatic changes in agricultural technology and productivity to make any significant inroads into poverty levels. Thus, providing a positive investment climate for agricultural and other rural workers is central to supporting growth and poverty reduction in developing countries.

The primary vectors through which the investment climate impacts on the level of agricultural productivity are: the existence of adequate infrastructure and communication networks; the extent to which transaction costs are minimised and policies are coherent and coordinated; access to finance, and particularly to short-term seasonal credit; and access to land and secure property rights (DFID 2005b). Skills and access to information and technology (e.g. mobile phones and fertilisers), as mentioned in the previous section, are also critical, particularly in lagging regions where there are few opportunities to raise productivity levels. There is some risk that general surveys on the investment climate may not accurately or sufficiently capture the challenges faced by farmers and other rural workers - necessitating a more indepth look at the links between investment climate and agricultural growth. An important further factor is the extent to which farmers face risk attributable to variations in weather, prices and the incidence of pests and diseases. Markets in, e.g. insurance, are typically too weakly developed in many parts of Asia to allow protection against these risks, and the higher their perception of risk, the less willing are farmers likely to be to invest. There is therefore a major policy opportunity in stimulating insurance and related markets, and in providing infrastructure which reduces risk, such as gravity irrigation.

Increases in agricultural production in Asia have been striking since the Green Revolution of the 1960s: between 1961 and 2001, annual production of cereals in Asia increased from 309 tons to 962 million tons due primarily to increases in land productivity: yields rose from an average of 1.2 to 3.3 tons per hectare while farmed land increased only 40 per cent (DFID 2005b). Secure property rights and support from governments have been central to making such gains possible: for example, at the start of the Green Revolution, India started investing in roads, education, irrigation infrastructure and agricultural research generating growth in the economy (DFID 2005b: 30). Similarly, in the early 1980s, Thailand began a 20-year project to title farmland in order to enhance farmers' access to credit and create secure property rights to generate incentives for long-term investment. World Bank evidence demonstrates that this process was successful both in the number of people who were registered (increasing from 4.5 to 18 million) and in terms of increasing productivity on titled land (World Bank 2005: 83). Some recent attempts to increase farmers' access to credit in India are outlined in Box 1.

Nonetheless, significant challenges remain for improving the investment climate for Asian 


\section{Box 2 Vietnam's easing of small business restrictions}

Since the late 1990s, Vietnam has been moving towards better macroeconomic stability and investment climate specific reforms such as easing business restrictions for SMEs. It entered into the Asia-Pacific Economic Cooperation (APEC) form and is committed to enter the ASEAN Free Trade Area by 2006

Most significant has been Vietnam's entry into a bilateral trade agreement with the USA in December 2001, followed by the completion of agreements on economic reform with the International Monetary Fund (IMF) and World Bank.

The ease of Vietnamese restrictions on small businesses in 2001 has led to rapid growth in Vietnam as millions of small subsistence farmers move into more efficient and productive endeavours (e.g. to farm coffee or prawns, or as labour in textile plants and shoe factories).

Sources 'Changing Gear', The Economist (26 November 2005). '2005 Investment Climate Statement: Vietnam', US State Department.

agricultural producers. Agricultural productivity is still low in many parts of Asia, trapping people in slow growth and poverty. In these still poor areas, there is evidence that no other sector will have the same impact on employment, linkages to non-farm growth and poverty reduction. Additionally, aggregate food sufficiency in Asia overlooks significant hunger in persistent pockets of poverty. In many of these regions, growth in basic staples is critical to ensure household food security via affordable agricultural workplaces. Making an effort to improve the investment climate for farmers is critical as failing to improve the investment climate in rural and agricultural producing regions of Asia could lead to rising levels of inequality in society and between subregions; a weakening of agricultural growth, with subsequent slowing of the overall pace of economic growth and poverty reduction; poor management of natural resources, compromising productivity and future growth; and increasing incidence of resource-related conflict; and/or increased food prices and subsequent increases in hunger and malnutrition.

\subsection{Non-agricultural domestic enterprises in Asia}

The investment climate has strong impacts on domestic firms of all sizes - from small enterprises to large corporations. Many of those engaged in private sector work in Asia as well as other parts of the developing world work in small- and medium-sized enterprises (SMEs), which 'are often considered the heart of a developing country's entrepreneurship the source of its new employment and productive investment, and the basis for its growth and elimination of poverty' (DFID 2005a: 9). Challenges in the investment climate fall disproportionately on micro-, small- and medium-sized enterprises, where regulatory burdens tend to be high, which in turn reduces incentives to invest or become part of the formal market (DFID 2005a). ${ }^{5}$

In Asia, as is demonstrated in the following section, there is great variation between the burdens on SMEs to do business; though progress has been made in some countries (see Box 2 on Vietnam). Reducing restraints on small producers creates a solid base for economic growth, and this is more directly related to the lives of poor people than larger companies in many cases.

Large domestic companies are also significant drivers of macroeconomic growth, make up a large percentage of the GDP, act as sources of employment in both cities and rural areas (e.g. factories in more rural Chinese regions) and are providers of foreign exchange through their links to the international markets. Such companies are generally in competition with multinational firms, both within their home markets, and in export markets. As such, the investment climate, and particularly elements of the investment climate which are linked to the outside world such as tariff and customs regulations and the state of ports and airstrips are especially important to large domestic companies. As briefly noted before, many Asian governments (particularly in East Asia) have historically chosen to prioritise these types of firms so as to increase their competitiveness vis-à-vis multinationals through various industrial policy tools. Such initiatives to improve the investment climate 


\section{Box 3 China encourages the domestic venture capitalist fund}

China has launched a drive to create a domestic venture capitalist industry to fund companies in highgrowth sectors such as technology. The move is likely to increase competition and reduce returns for foreign private equity groups.

The initiative by the National Development and Reform Commission (NDRC), China's chief economic planning body, is designed to foster home-grown venture capitalists by offering them better tax treatment and easier exit routes than foreign rivals.

The NDRC's rules encourage local governments to provide direct investments, loans and debt guarantees to domestic venture capital funds, which will be required to have only Chinese nationals among top management and investors.

The measures, expected to come into force in March 2006, could help address the funding problems of most Chinese small companies, which are regularly shunned by state banks who favour government-owned enterprises.

Source 'Move to boost Chinese capital', Financial Times (23 November 2005).

for large domestic enterprises need not be specifically designed to prioritise domestic over foreign business. One example is contained in Box 3 on a recent initiative to provide venture capital for Chinese entrepreneurs.

\subsection{The investment climate and multinational corporations in Asia}

The final sector to which the investment climate is a central concern is multinational corporations investing in Asia; which continue to increase in number. The investment climate is central to determining the flows of FDI, for example, which is a major source of GDP growth and foreign exchange earnings. FDI also encourages an increase in exports in many cases, and can lead to technology transfer to host countries. Within Asia, there is some difference between the attractiveness of individual countries for inflows of FDI. While China was the largest receiver of FDI in the world in 2003 (overtaking the USA), East Asia and South-east Asia in general receive a high proportion of FDI relative to their economic size than is warranted - i.e. the ratio of East Asia's global FDI inflows to its share of global GDP is greater than one, and is in fact 1.54 . The same metric for South and West Asia, in contrast was far below one: 0.37 and 0.31, respectively (Rahman 2005).

Asian governments have implemented an array of policies designed to attract FDI, with varying degrees of success on both economic and social indicators. ${ }^{6}$
One policy tool used by many governments in the Asian region is the signing of bilateral investment treaties (BITs) which provide protection to multinational investors. Bangladesh, Hong Kong, India, Indonesia, Korea, Laos, Malaysia, Nepal, Pakistan, the Philippines, Singapore, Sri Lanka, Thailand and most recently Vietnam have signed BITs with the UK and numerous other governments (UNCTAD 2000). In theory, BITs should act as a commitment mechanism, by which developing countries commit themselves to 'safe' treatment of foreign investment, in turn increasing the amount of investment a country with otherwise weak institutions or weak credibility receives. However, there is a trade-off between the stability provided for investors by BITs and their constraint on governments (especially during times of economic and financial crises) and empirical evidence on the impact of BITs on attracting investment has been mixed. Some researchers have found that the attraction of FDI is positively linked to signing BITs, but that BITs act as a complement rather than a substitute for strong political and legal institutions (Hallward-Driemeier 2003; Tobin and Rose-Ackerman 2005). Others have found a strong relationship between signature of BITs from certain home countries (e.g. the USA) and FDI flows (Salacuse and Sullivan 2005).

Individual Asian governments have also undertaken tax and regulatory reform to create incentives for both international and domestic investment; one such example is Singapore (see Box 4). 


\section{Box 4 Singapore's e-government initiative}

Advances in information technology, including the internet, are paving the way for investment climate improvements that reduce demands on public administration, enhance transparency, and easy compliance burdens on firms.

The e-government initiative launched by Singapore in 2000 included business registration and licensing procedures. It provides an online application system for business registration and licensing and a one-stop online application system for certain special licences that previously required separate submissions to as many as 12 regulatory authorities.

The integrated approach reduced the cost of incorporating a new company from anywhere between US\$700-20,000 to a flat fee of US\$175. What used to require two days now requires less than two hours. Streamlining the submission process for construction permits saves applicants more than US\$260.

Source 'E-government and investment climate', World Development Report 2005, World Bank (2005: 54).

\section{Analysing the current investment climate in \\ Asia}

A more systematic view of the Asian investment climate can be obtained by analysing sources for detailed empirical information about cross-national differences in the investment climate. Two such studies have been gathered by the World Bank: the Investment Climate Surveys (ICS) and the Doing Business Surveys (DBS). The two differ in terms of the sources of data, types of issues covered and periodicity. ${ }^{7}$ The ICS covers fewer countries as well (10 as opposed to 18). Using these two data sources in addition to some private sector estimates of

\section{Figure 2 Variation of investment climate among}

\section{Chinese cities}

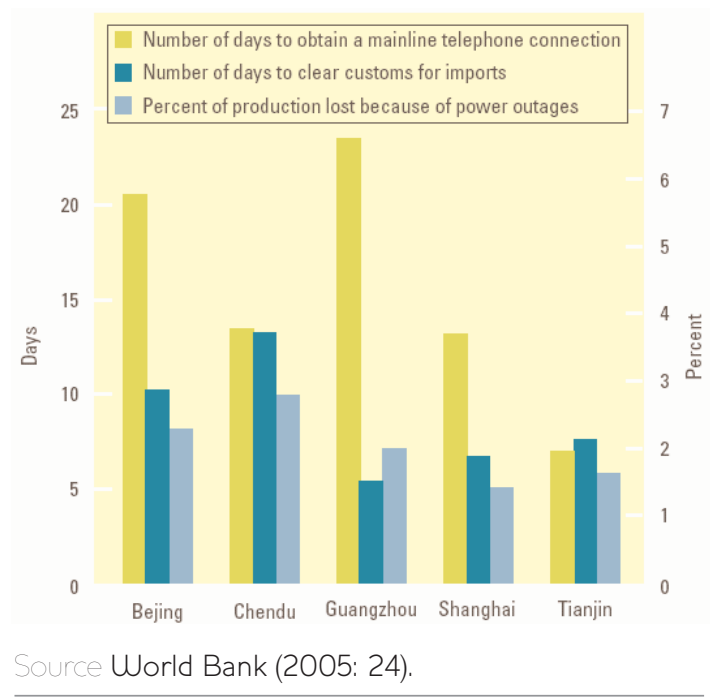

business climate (e.g. the Economist Intelligence Unit, or EIU) provides a good initial picture of how far Asian economies have gone in creating a conducive investment climate, and helps to identify areas in which challenges remain. That said, a serious failing of the surveys is that they often fail to accurately reflect challenges faced by rural and agricultural firms in particular.

As noted earlier, the investment climate in Asia can generally be subdivided regionally - East Asia has implemented more 'best practice' measures than South Asia, increasing the overall strength of the investment climate, though there are substantial differences within these regions. As McLeish and Martin (2005: 1) note: 'South Asia imposes some of the highest regulatory obstacles to running a company in the world, second only to sub-Saharan Africa in the overall difficulty of doing business'. Nonetheless, they note that it is relatively easy to start a business in South Asia given the lack of minimum capital requirements and procedural hurdles. While these trends tend overall, there is significant variation among countries even within Asian subregions, among elements of the investment climate within single countries, and even variation within regions of single countries, as Figure 2 demonstrates.

As such, the remainder of this section attempts to categorise countries along investment climate issues (economic and political risk, rule of law, infrastructure etc.) in order to get a better picture of the investment climate in Asia as a whole. 
Figure 3 Percentage of firms reporting political or economic risk as impediment to business

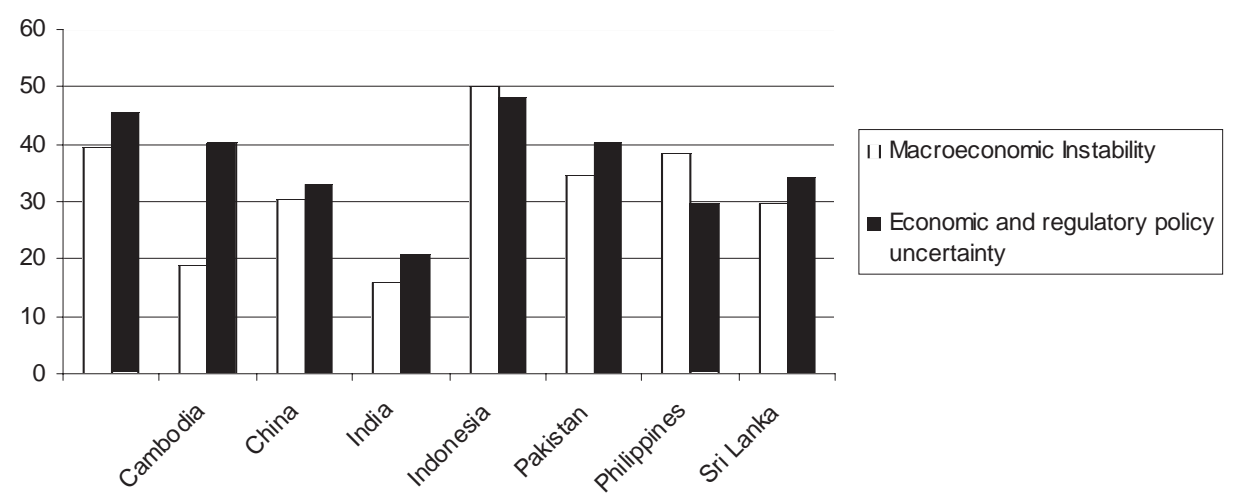

Compiled from World Bank 'Investment Climate Surveys'.

\subsection{Governance}

\section{Economic and political stability}

While the introductory section demonstrated that macroeconomic and political uncertainty were strong drivers of negative perceptions of the investment climate in most of Asia, these two elements of the investment climate play a less central role. None of the firms thought that policy uncertainty was the largest problem in the countries surveyed, though macroeconomic instability was the top concern in Indonesia and the Philippines. ${ }^{8}$

As is demonstrated in Figure 3, there is substantial variation in the perception of macroeconomic and political instability among Asian countries covered in the ICS. Both variables are of the largest concern in Indonesia, ${ }^{9}$ and are notably lower in both India and
China. One interesting note is that larger Chinese firms (250+ employees) more often said that economic and regulatory policy uncertainties were a major or very severe obstacle to business than other types of firms. There was little variation among sectors. The same was true to a lesser degree for India, though those in the garment and textile sectors were considerably more concerned about such risks.

Interestingly, according to the EIU which looks at such issues from a perspective more oriented towards international investors, the risk in Indonesia is thought to be less than that in Pakistan and China, for example (Figure 4). Additionally, it is worth noting that political stability and government effectiveness is consistently thought to be a significantly larger problem across Asia than macroeconomic risk, with the exception of Japan.

\section{Figure 4 Economic and political stability as measured by the EIU}

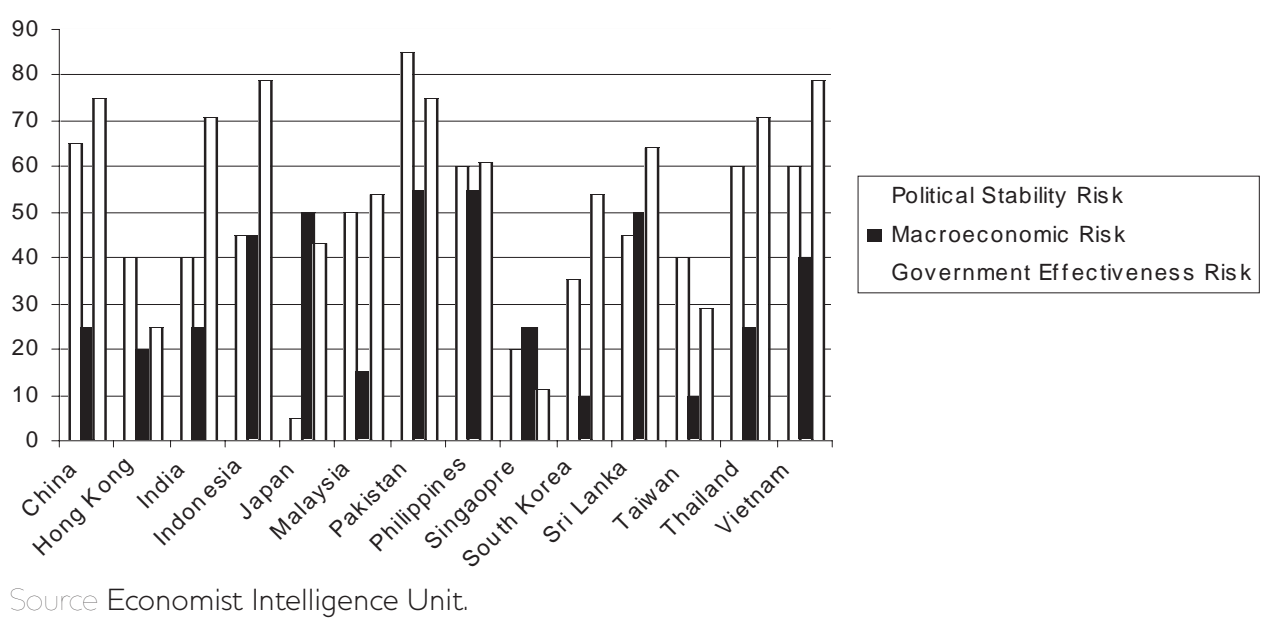




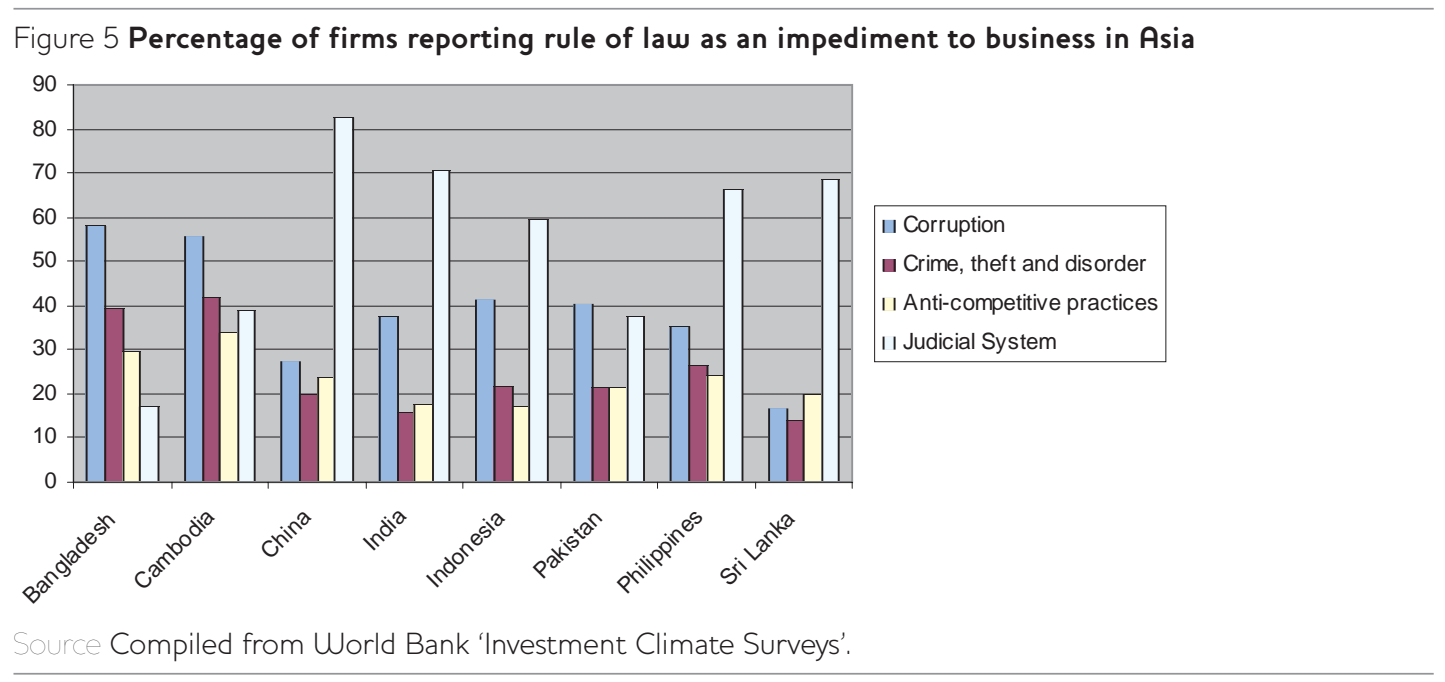

\section{Rule of law}

Figure 5 attempts to compare Asian economies across corruption, crime theft and disorder, anticompetitive practices, and the strength of the judicial system (where a higher indicator shows confidence in the judicial system - in contrast to the rest of the indicators). Confidence in the judicial system is pronounced in China, India, Indonesia, the Philippines and Sri Lanka. In India, confidence in the judiciary was markedly different between foreign and domestic investors, as the former had greater faith in the judicial system to enforce their claims (71 per cent as opposed to 56 per cent). In China, both domestic and international firms had about 80 per cent confidence in the judicial system. There is little indication in the surveys whether perception of rule of law varies among small and rural investors, who may have heightened concerns about the arbitrariness of local systems of justice.
Also notable from Figure 5 is that the perception of corruption is much higher in Bangladesh and Cambodia than in the other Asian countries surveyed This is consistent with Transparency International's (TI) Corruption Perception Index, which ranks these two countries last (Bangladesh and Chad tie for most corrupt) and 130 out of 158, respectively. Pakistan is perceived as significantly more corrupt under Tl's indicators: 144 out of 158. ${ }^{10}$ Similarly, the perception of anti-competitive practices and crime, theft and disorder in Bangladesh and Cambodia are higher than in other countries by some margin.

\section{Tax and regulations}

The metrics for analysing regulations in Asia are best analysed by looking at results from the DBS, which cover a wide array of Asian countries. Tables 2, 3 and 4 present selected information from the DBS according to region. It is interesting to note that

\section{Table 2 Doing business in South Asia}

\begin{tabular}{|c|c|c|c|c|}
\hline & Bangladesh & India & Pakistan & Sri Lanka \\
\hline Starting a business (days) & 35 & 71 & 24 & 50 \\
\hline Dealing with licenses (days) & 185 & 270 & 218 & 167 \\
\hline Registering property (days) & 363 & 67 & 49 & 63 \\
\hline Paying taxes (hours) & 640 & 264 & 560 & - \\
\hline $\begin{array}{l}\text { Trading across borders } \\
\text { (export/import) }\end{array}$ & $35 / 57$ & $36 / 43$ & $33 / 39$ & $25 / 27$ \\
\hline Closing a business (years) & 4.0 & 10.0 & 2.8 & 2.2 \\
\hline
\end{tabular}

Source Compiled from World Bank 'Doing Business Surveys'. 
Table 3 Doing business in South-east Asia

\begin{tabular}{llllllll}
\hline & Cambodia & Indonesia & Malaysia & Philippines & Singapore & Thailand & Vietnam \\
\hline Starting a business (days) & 86 & 151 & 30 & 48 & 6 & 33 & 50 \\
Dealing with licences (days) & 247 & 224 & 281 & 197 & 129 & 147 & 143 \\
Registering property (days) & 56 & 42 & 143 & 33 & 9 & 2 & 67 \\
Paying taxes (hours) & 97 & 560 & - & 94 & 30 & 52 & 1,050 \\
Trading across borders & $43 / 55$ & $25 / 30$ & $20 / 22$ & $19 / 22$ & $6 / 8$ & $23 / 25$ & $35 / 36$ \\
(export/import) & & & & & & & \\
Closing a business (years) & - & 5.5 & 2.2 & 5.7 & 0.8 & 2.7 & 5.0 \\
\hline
\end{tabular}

Source Compiled from World Bank 'Doing Business Surveys'.

within South Asia, it is more difficult on some metrics to do business in India than in Bangladesh, in contrast with the statistics above.

Table 3 focuses on South-east Asia and demonstrates that while it is easier to start and close a business in Malaysia and Thailand than elsewhere in the region, it can still take a significant amount of time to process a licence, and few gains are made on import and export days. Singapore's performance on such indices stands out - as do the tax statistics for Vietnam, where there are 44 types of payment and it takes more than 1,000 hours to pay taxes.

The group of East Asian countries and territories in Table 4 represent a mix of high-income countries and developing countries, and generally doing business in this region seems easier than in most of South or South-east Asia (with the exception of Singapore). China's metrics are comparable with Sri Lanka's and still some way from South-east Asian countries such as Malaysia or Thailand, as well as most other East Asian comparisons.

The ICS also provide information about the role of tax rates and administration, as well as adding some information about business customs, licensing and permits. In Figure 6, Pakistan and Bangladesh appear in particular to have difficult investment climates; tax rates are considered to be a greater burden in China than in India, as are customs and business licensing requirements. This illustrates that the perceptions are slightly different from those obtained through interviewing tax, legal and business specialists in capital cities (the data source for the DBS).

The information from the EIU has findings closer to that of the DBS in terms of the India/China comparison, suggesting that the different perceptions could come from foreign versus domestic perspectives on tax and regulation. The complete EIU risk rankings are shown in Figure 7.

\section{Table 4 Doing business in East Asia}

\begin{tabular}{llllll}
\hline & China & Hong Kong & Japan & Korea & Taiwan \\
\hline Starting a business (days) & 48 & 11 & 31 & 22 & 48 \\
Dealing with licences (days) & 363 & 230 & 87 & 60 & 235 \\
Registering property (days) & 32 & 83 & 14 & 11 & 5 \\
Paying taxes (hours) & 584 & 80 & 315 & 290 & 296 \\
Trading across borders (export/import) & $20 / 24$ & $13 / 16$ & $11 / 11$ & $12 / 12$ & $14 / 14$ \\
Closing a business (years) & 2.4 & 1.1 & 0.6 & 1.5 & 0.8 \\
\hline
\end{tabular}

Compiled from World Bank 'Doing Business Surveys'. 


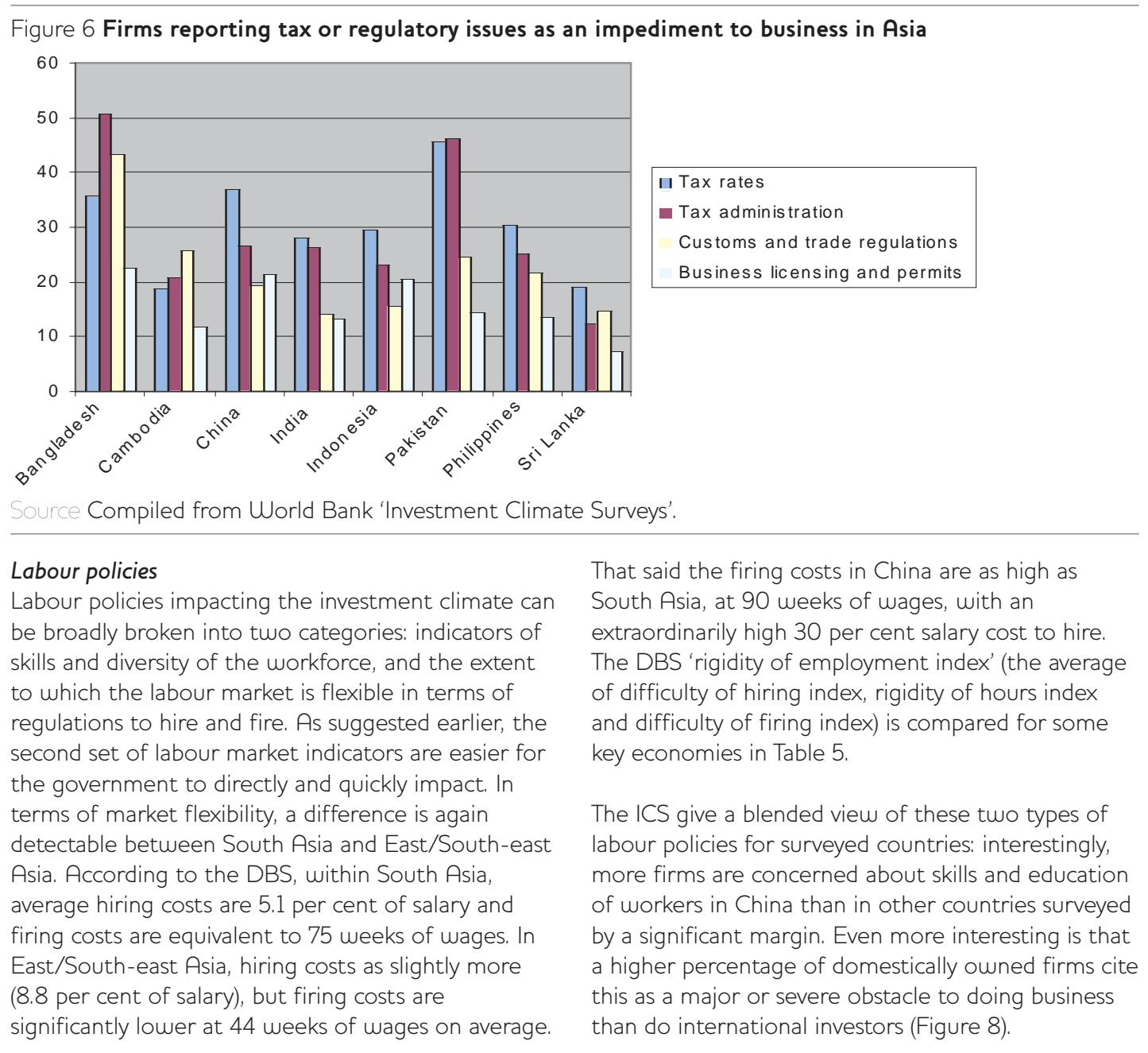

\section{Figure 7 Tax policy and foreign trade risk in Asia}

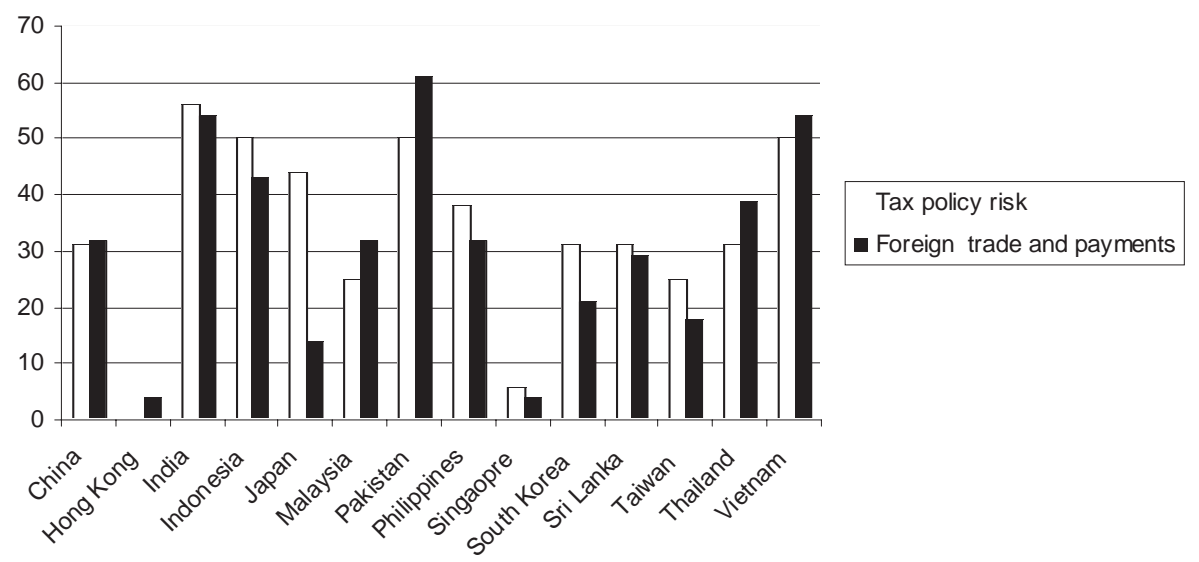

Economist Intelligence Unit. 
Table 5 Labour flexibility in selected Asian economies

\section{Rigidity of employment index}

$\begin{array}{ll}\text { Bangladesh } & 24 \\ \text { China } & 30 \\ \text { India } & 62 \\ \text { Indonesia } & 57 \\ \text { Malaysia } & 10 \\ \text { Thailand } & 18 \\ \text { Vietnam } & 51\end{array}$

Source Compiled from World Bank 'Doing Business Surveys'.
Additional information on the social indicators of labour policies can be obtained through the ICS. Table 6 categorises skills and social indicators of labour across several economies. Notice that the level of training provided in China is much higher than in other economies, and that Pakistan is the only country to provide figures on the role of women in senior management.

Finally, the EIU provides a metric of labour market risk, showing that risk is highest in Vietnam and Indonesia; labour market risk in China and India is high and identical (Figure 9).

\subsection{Infrastructure}

\section{Infrastructure constraints}

Infrastructure constraints in South Asia are perceived to be significantly more severe than in South-east and East Asia. The data for Bangladesh in particular is

Table 6 Labour flexibility in selected Asian economies

\begin{tabular}{llllll}
\hline & $\begin{array}{l}\text { Females in senior } \\
\text { management (\%) }\end{array}$ & $\begin{array}{l}\text { Firms offering } \\
\text { formal training (\%) }\end{array}$ & $\begin{array}{l}\text { Workers receiving } \\
\text { training (\%) }\end{array}$ & $\begin{array}{l}\text { Unionisation } \\
\text { (\%) }\end{array}$ & $\begin{array}{l}\text { Production days } \\
\text { lost to strikes }\end{array}$ \\
\hline Bangladesh & - & 27 & 33 & 11 & 0.3 \\
China & - & 85 & 48 & 66 & 0.3 \\
India & - & - & - & 62 & - \\
Indonesia & - & 24 & - & 43 & 1.1 \\
Pakistan & 3.2 & 11 & 36 & 5 & 0.6 \\
Philippines & - & 22 & 27 & 12 & 0.8 \\
\end{tabular}

Source Compiled from World Bank 'Investment Climate Surveys'.

\section{Figure 8 Firms reporting labour regulations or skills as an impediment to business in Asia}

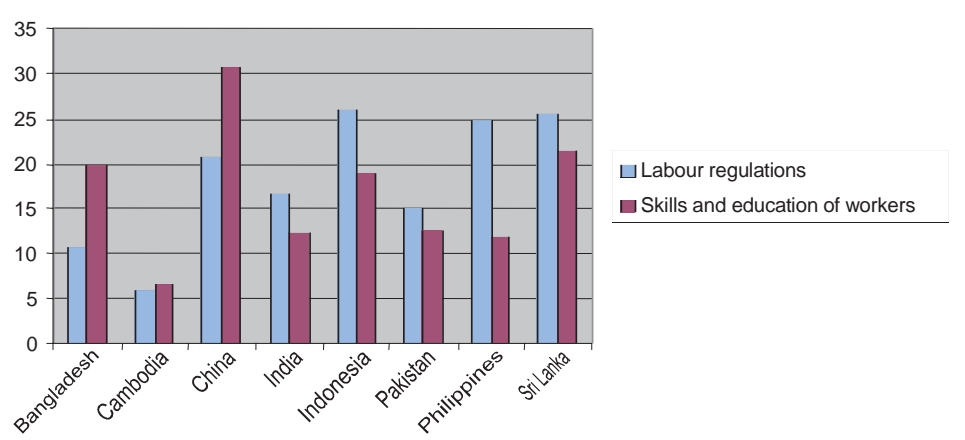

Source Compiled from World Bank 'Investment Climate Surveys'. 


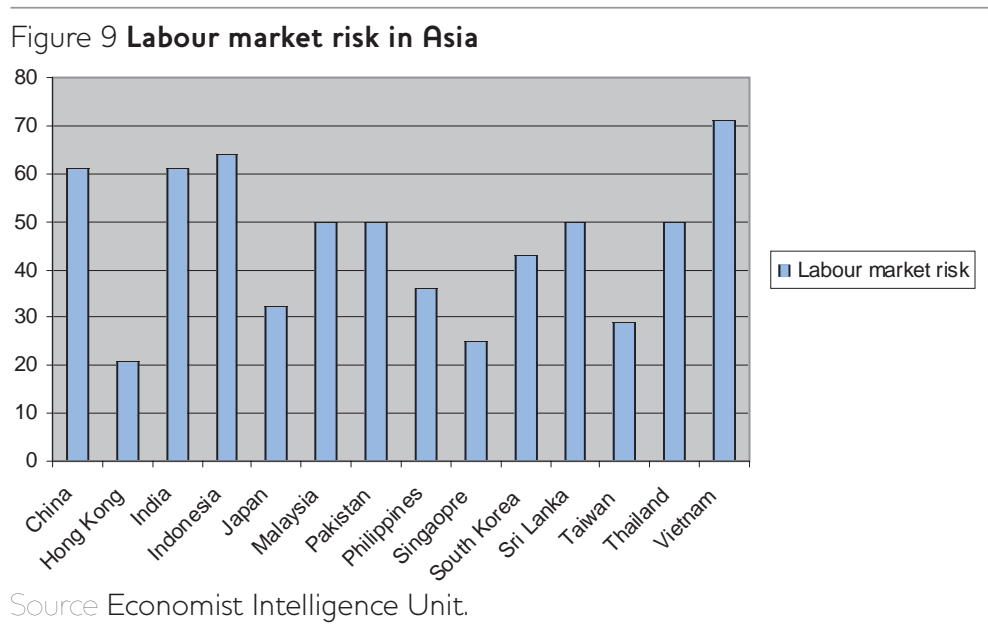

striking: the ICS report that the delay in obtaining an electrical connection in Bangladesh is 80 days and electrical outages are reported nearly 250 days a year. The time to obtain an electrical licence in India is even longer ( 82 days), though no data is available on the degree of power outages. These statistics are less severe, though still concerning, in other South Asian states. Comparative statistics on South Asia are given in Table 7.

Figure 10 demonstrates that electricity is thought to be by far the largest constraint to business in Asia (note that the problem is perceived to be more acute in China than in India). Though no data is available for China on days of electrical outages, a significantly smaller percentage of sales are said to be lost through electrical outages (1.9 per cent).

\section{Finance}

Access to finance in Asia depends both on country and industries, and there is a large amount of information about such constraints in the Asian context. First, the ICS provide descriptive information about the availability and efficiency of finance in various countries (shown in Table 8).

These statistics, however, obscure significant differences in access to credit across size of businesses and sectors. Table 9 shows the collateral needed and overdraft statistics for the same countries by size of firm."

As Table 9 shows, small firms face obstacles in almost all countries to accessing an overdraft, and in many cases, collateral rates are higher for small firms

\section{Table 7 Infrastructure constraints in South Asia}

\begin{tabular}{lllll}
\hline & Bangladesh & India & Pakistan & Sri Lanka \\
\hline Electrical connection (days to establish) & 80 & 82 & 33 & 65 \\
Electrical outages (days) & 249 & - & 15 & - \\
Value lost to outages (\% of sales) & 3.3 & 9.0 & 5.4 & - \\
Water connection (days to establish) & 32 & - & 5 & 12 \\
Value lost to failures (\% of sales) & 150 & 87 & 25 & 63 \\
Telephone outages (days) & 71 & 64 & 42 & 75 \\
Value lost to outages (\% of sales) & 70 & 62 & 34 & 68 \\
Firms that oun/share a generator & 31 & 36 & 18 & 29
\end{tabular}

Compiled from World Bank 'Investment Climate Surveys'. 


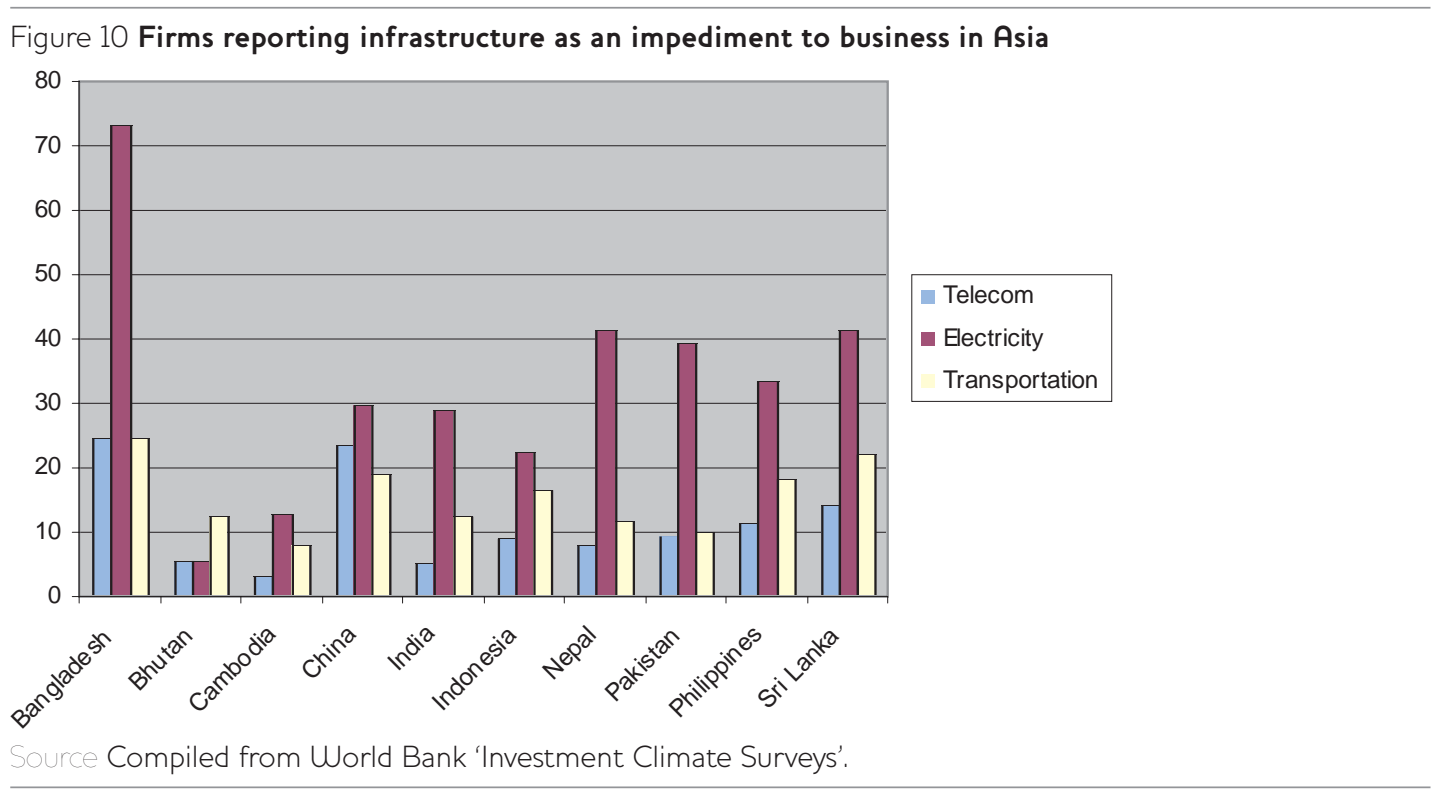

than in medium and large firms (Figure 11). More broadly, the firm perception surveys from the ICS provide a sense of the overarching constraint of finance to the country: cost and access to financing are particularly problematic in Bangladesh and Pakistan.

\section{Ways forward}

This article has served to review the concept of the investment climate as well as the information available on the current practice in Asia. This section attempts to draw from this analysis, and suggests several ways forward both for governments and for partnerships regionally and internationally.
First, it is worth noting that while much of the discussion about the investment climate focuses on the growth benefits that can be derived from investment climate reform, little attention is generally paid to the financial and political costs of reform. Though Asian governments may desire to reform the investment climate, there are often political economy constraints to doing so, given the nature of reforms. As was mentioned in the discussion of centralised versus decentralised investment climate policy, the investment climate in many countries has traditionally been determined through a process of aggregation of individual policies, which may stem from

governments' efforts to prioritise particular sectors or

Table 8 Access to finance in selected Asian economies

\begin{tabular}{llllll}
\hline & $\begin{array}{l}\text { New finance } \\
\text { from internal } \\
\text { funds (\%) }\end{array}$ & $\begin{array}{l}\text { New investment } \\
\text { from banks (\%) }\end{array}$ & $\begin{array}{l}\text { Firms with } \\
\text { an overdraft } \\
\text { facility (\%) }\end{array}$ & $\begin{array}{l}\text { Collateral } \\
\text { needed for } \\
\text { a loan (\%) }\end{array}$ & $\begin{array}{l}\text { Days to clear } \\
\text { a cheque }\end{array}$ \\
\hline Bangladesh & 60 & 30 & 66 & 95 & 2.9 \\
China & 27 & 36 & 24 & 85 & 4.5 \\
India & - & - & 58 & 101 & 11.1 \\
Indonesia & 42 & 16 & 20 & 116 & 14.3 \\
Pakistan & 58 & 7 & 23 & 72 & 1.9 \\
Philippines & 58 & 13 & 31 & 61 & - \\
\hline
\end{tabular}


Table 9 Access to finance in selected Asian economies, by firm size

\begin{tabular}{lllllll}
\hline & \multicolumn{2}{l}{ Firms with an overdraft facility (\%) } & \multicolumn{2}{l}{ Collateral needed for a loan (\%) } \\
& Small & Medium & Large & Small & Medium & Large \\
\hline Bangladesh & 53 & 69 & 72 & 80 & 98 & 97 \\
China & 12 & 23 & 39 & 98 & 85 & 82 \\
India & 52 & 71 & 90 & 100 & 99 & 110 \\
Pakistan & 16 & 40 & 58 & 76 & 68 & 64 \\
Philippines & 19 & 44 & 45 & 62 & 55 & 69 \\
\hline
\end{tabular}

Source Compiled from World Bank 'Investment Climate Surveys'.

regions. As such, interests in maintaining the status quo may be enhanced by entrenched preferences among corporate actors or local and regional governments which benefit from current arrangements. Therefore, the process of migrating to a centralised investment climate policy framework, or revising individual aspects which depress pro-poor growth, is often very difficult for governments. While there are no easy methods to solving this problem (perhaps especially in democracies where the electoral prospects of governments may be tied to maintaining support from key constituents), policies can be designed in coordination with such actors to ensure that the process of transition is more easily accomplished. Additionally, governments can utilise data on likely benefits from such reform (e.g. incremental growth rates) to facilitate change.

Thus, while prioritisation of reform must be determined by individual governments based both on needs identified through firm level data and political analyses of costs and benefits of reform, the evidence reviewed in this article demonstrates that there are two areas in which most Asian governments would benefit from focusing reform efforts: encouraging investment in infrastructure and reducing the regulations which increase the time costs of doing business. Additionally, given that the Asian region has demonstrated that high levels of growth are possible without implementing a full investment climate reform programme, it is important that interventions be selected to facilitate pro-poor growth. This means in particular investigating the legal, land and regulatory constraints faced by agricultural and rural enterprises, as many of the region's poor people live in so-called 'lagging regions' which tend to be predominantly rural and driven by agricultural industries. This is equally true for those countries where growth rates have underperformed the regional average.

\section{Figure 11: Access to and cost of financing}

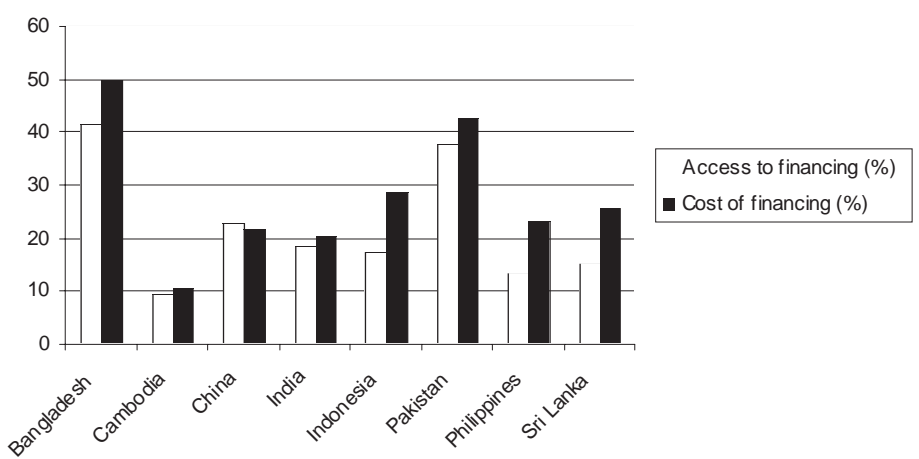

Compiled from World Bank 'Investment Climate Surveys'. 
Achieving such goals requires government initiatives as well as regional and international efforts. Outlined below are some of the general ways in which regional and international efforts can contribute.

- As mentioned previously, international organisations have thus far been instrumental in providing high-quality micro-level data about constraints to business climates in many Asian countries. Given this data, international institutions can seek to engage with Asian governments to help in assessing the costs and benefits of each government's proposed reform programmes and doing further work on the growth elasticities on individual elements of the investment climate. Additional means of pragmatically helping to implement reform include providing suggestions about how to facilitate national discussions with important stakeholders; suggestions which should be derived from experiences in other countries and regions.

- In line with the above, it would be useful for Asian governments to discuss such successful reform processes with one another. International institutions (especially those with a regional mandate such as the Asian Development Bank) can facilitate meetings designed to encourage such interaction and knowledge sharing. To some extent, promoting regional links in other topic areas (such as trade) will naturally facilitate a greater harmonisation of key aspects of the investment climate - such as regulatory regimes International partners can therefore facilitate these opportunities by reviewing their bilateral, regional and multilateral trade partnerships with Asia for matters in which regional cooperation can occur, including simplifying rules of origin under regional preference schemes.

Some specific suggestions on a future agenda for action derived from these points include:
- In the context of agriculture and the investment climate in rural areas to enhance pro-poor growth, greater efforts could be made to reform public expenditures that favour large landowners, such as subsidised groundwater extraction for irrigation. Additionally, efforts must be made to enable a gradual transition to high-value crops, a more diversified agriculture and broader employment opportunities for poor people. Finally, there is a need to strengthen policies and institutions and deploy economic, legal and social instruments to tackle resource degradation which compromises the efficiency and sustainability of resource use. International agencies must, in turn, be willing to dedicate a greater degree of resources to rural and agricultural programmes.

- More must be done to scale-up work on competition policy including building capacity of governments to conduct competition assessments and analyse the impact of regulations on key sectors of the economy. Additionally, analysis and revision of commercial laws that have adverse impacts on business competition should be supported. ${ }^{12}$

- Additional analysis of financial constraints to investment should be undertaken. The UK Department for International Development (DFID) and the World Bank are initiating work on access to finance by conducting surveys of access to finance to underpin policy reform and commercial innovation in Asia. This work is being carried out to date in India, Bangladesh and Pakistan and could be expanded.

- DFID is planning to set up a Regulatory Impact Analysis Unit in the Bangladeshi central government, in an attempt to implement better regulatory systems at the national level. Such measures are also needed at the regional level and in other countries.

- A more effective and systematic public-private dialogue process should be encouraged to engage the private sector's help in improving public policy for private sector development in the region. 


\section{Notes}

1 One issue that is generally not included in the investment climate but is critical to the incentives to invest and returns for all types of firms are geographical issues such as the benefits that accrue to firms through clustering and agglomeration. There is a large sub-field of economics literature on this topic, which will not be reviewed here. However, it is important to consider the investment climate within broader discussions of urban planning and geography.

2 Additionally, infrastructure is both a part of the investment climate and is itself influenced by the investment climate: a poor investment climate, particularly a defective regulatory framework, can discourage private investment and public-private partnerships in infrastructure.

3 One particular way in which countries can ensure that the smallest borrowers in rural areas have sufficient access to credit is by encouraging the development of microfinance credit organisations. Microfinance has been shown to increase household incomes and allow for income diversification. In some cases, e.g. the Grameen Bank in Bangladesh, which was one of the first of its type, microfinance has also played a strong role in the empowerment of women. The World Bank estimates that in 2002 there were more than 1,000 microfinance organisations operating in the world, lending a total of US $\$ 3.5$ billion to 30 million borrowers (World Bank 2005: 120). Access to microfinance is particularly important in the rural and agricultural context.

\section{References}

ADB (2005) Asian Development Outlook 2005, Manila: Asian Development Bank

Castanhar, J.C. (2003) 'Fiscal Federalism in Brazil: Historical trends, present controversies and future challenges', presented at the VIII International Congress on State Reform and Public Administration in Latin America and the Caribbean, Panama: 28-31 October

DFID (2005a) Working with the Private Sector to Eliminate Poverty, London: Department for International Development

DFID (2005b) Productivity Growth for Poverty Reduction: An Approach to Agriculture, London: Department for International Development

Dollar, D., Hallward-Driemeier, M. and Mengistae, T. (2003) Investment Climate and Firm Performance in Developing Economies, London School of Economics STICERD Working Paper
4 An arm of the multinational consultancy group.

5 Many SMEs in Asia are rural or agricultural-based enterprises, and thus there is significant overlap between these two groups.

6 For example, in China, previous laws which privileged foreign investment in eastern coastal regions have enhanced inequality with western provinces and rural areas.

7 While ICS analyses an array of variables through firm-based surveys and categorises information in terms of size of enterprises, as well as looking for differences within countries (by cities or regions), the DBS is compiled by interviewing legal, tax and finance professionals based in large business centres (generally national capitals) about the time and monetary costs of setting up and conducting business. It has been conducted and revised with greater frequency, given the easier access to data involved.

8 Countries included were Bangladesh, Cambodia, China, India, Indonesia, Pakistan, the Philippines and Sri Lanka.

9 Disaggregated data is not available for Indonesia by firm size or sector.

10 The 2005 Corruptions Perception Index is available on www.transparency.com

11 No information is available for Indonesia by firm size.

12 DFID is undertaking such actions in the context of Bangladesh.

Ellis, K. (2005) 'Increasing Access to Financial Services,' presented at the Commonwealth Finance Ministers Meeting, Barbados, 18-20 September

Hallward-Driemeier, M. (2003) Do Bilateral Investment Treaties Attract Foreign Direct Investment? Only a Bit... and They Could Bite, World Bank Research Working Paper 3121, Washington DC: World Bank

McLeish, C. and Martin, F. (2005) 'Implementing Regulatory Reform: What to Reform and Who to Learn From', paper presented at the Third South Asian Investment Roundtable on Best Practice in Implementing Regulatory Reform, Dhaka, 13-14 June

Palmade, V. (2005) 'Industry Level Analysis: The Way to Identify the Binding Constraints to Economic Growth', paper presented at Reforming the Business Environment: From Assessing Problems 
to Measuring Results, Cairo, 29 November1 December

Rahman, A. (2005) 'South Asia: Perceptions of Business and Investment Environment', paper presented at the Third South Asian Investment Roundtable on Best Practice in Implementing Regulatory Reform, Dhaka, 13-14 June

Salacuse, J. and Sullivan, N. (2005) 'Do BITs Really Work: An Evaluation of Bilateral Investment Treaties and Their Grand Bargain,' Harvard Journal of International Law 46: 67-130

Serra, J. and Afonso, J.R. (1999) 'O Federalismo Fiscal A Brasileira: Algumas Reflexoes', paper presented at Forum of Federations - International Conference on Federalism, Mont-Tremblant, 6-8 October
Stone, A. (2005) 'Reforming Regulation in South Asia: Experiences and Possibilities', paper presented at the Third South Asian Investment Roundtable on Best Practice in Implementing Regulatory Reform, Dhaka, 13-14 June

Tobin, J. and Rose-Ackerman, S. (2005) Foreign Direct Investment and the Business Environment in Developing Countries: The Impact of Bilateral Investment Treaties, New Haven: Yale University

UNCTAD (2000) Bilateral Investment Treaties 1959-1999, UNCTAD World Paper (UNCTAD/ITE/IIA/2), Geneva: United Nations

World Bank (2005) World Development Report 2005: A Better Investment Climate for Everyone, Washington DC: World Bank 